Laboratorio de Arte,4-1991 http://dx.doi.org/10.12795/LA.1991.i04.11

\title{
RETABLOS Y ESCULTURAS DEL BEATERIO DE LA TRINIDAD DE SEVILLA
}

\author{
por Juan Miguel González Gómez y José María Morillas Alcázar
}

En el presente trabajo acometemos el estudio y catalogación de los retablos, homacinas y esculturas de la iglesia, coro bajo, antecoro y sacristía del Beaterio de la Trinidad de Sevilla. En total se reseñan pormenorizadamente cuatro retablos, ocho hornacinas y veinticinco esculturas. Cronológicamente, todas estas piezas artísticas pueden situarse desde los inicios del siglo XVII hasta la primera mitad del siglo $\mathrm{XX}$.

This is a study and catalogue of the altarpieces, niches and sculptures of the main church, lower choir, apse and sacristy of the Beaterio de la Trinidad in Seville. In total we give a detailed account of four altarpieces, eight niches, and twenty-five sculptures. All these works of art can be dated from the beginning of the 17 th century to the first half of the twentieth.

En este estudio analizaremos los retablos y esculturas que exornan actualmente el interior de la iglesia, coro, antecoro y sacristía del Beaterio de la Trinidad de Sevilla. Dicho establecimiento de caridad fue fundado por D." Isabel Moreno Caballero en 1719. Desde su inicio es un centro educativo para "niñas pobres y ricas, huérfanas y con padres" '.

Documentalmente se sabe que el 22 de junio de 1719, ante el escribano público D. José González Bejarano, las religiosas permutaron, con el convento

1. GONZÁLEZ DE LEÓN, Félix: Noticia artística, histórica y curiosa de todos los edificios públicos, sagra. dos y profanos de esta Muy Noble, Muy Leal, Muy Heroica e Invicta Ciudad de Sevilla. Tomo I, Sevilla, 1844, p. 98. 
de la Santísima Trinidad, las casas de la fundación de la calle Enladrillada por dos casas y un solar en la calle Santa Lucía. En estas "casas y solar se labraron las primeras piezas de él" ?

Para construir dicho edificio realizó la fundadora dos viajes a Méjico (174650 y 1753-58). Con las limosnas obtenidas, que ascendieron a 14.000 pesos, continuó "la obra e hizo viviendas para este Beaterio, aunque hubiese doce Beatas; labró iglesia, coro, dos sacristías y una tirante para el patio principal" 3 .

Tras la muerte de Madre Isabel, acaecida el 8 de mayo de 1774, el Beaterio se mantuvo gracias a la benéfica tutela de D. Bartolomé Cabello, racionero de la Santa Iglesia Catedral de Sevilla.

Precisamente, este sacerdote fue quien completó el templo conventual que aún estaba inconcluso cuando falleció la fundadora. Razón por la que tuvo que recibir sepultura en la cercana parroquia de Santa Lucía.

La iglesia del Beaterio de la Trinidad se abrió al culto público en 1790 . Fue bendecida por el conocido bienhechor D. Bartolomé Cabello ${ }^{4}$. No obstante, con objeto de ampliarla, dicho sacerdote adquirió al Cabildo Catedral, el 11 de junio de 1802, unas casas, propiedad de la iglesia de Santa María la Blanca por 11.574 reales. Dichas casas lindaban por el norte, sur y este con el Beaterio y por el oeste con la calle del Caño. En este solar "labró dicho Señor: Capilla Mayor, Coro, Sacristías, Patios para luces y Dormitorio encima del Coro" 5.

Una vez ultimada esta remodelación, la iglesia que nos ocupa ofrecía la estampa que de ella nos facilita Félix González de León en 1844. Textualmente dice así: "La iglesia es sumamente estrecha, pues no es más que un cañón largo, pero muy angosto, cortado por un tercio con rejas para los respectivos coros, bajo y alto de las beatas y educandas" "6. Posteriormente, en 1897, José Gestoso y Pérez amplía dicha descripción en los siguientes términos: "la iglesia es de una sola nave, muy estrecha y larga y cubierta en toda su extensión por techumbre plana. A los pies de ella están los coros alto y bajo, que sirven a las Madres beatas, a cuyo cargo está la dirección del Establecimiento. Hay otro, con reja, para las educandas, que da al presbiterio en su muro de la epístola" ?

A raíz de nuestra labor investigadora sabemos que en el interior del templo se disponían los siguientes retablos e imágenes. La capilla mayor, acabada en testero plano, presentaba el retablo principal, aún conservado, donde se expone como

2. (A)rchivo (B)eaterio (T)rinidad (S)evilla. Libro de Protocolo de el Santo Beaterio de la Santíssima Trinidad, seminario de Niñas huérfanas. Año 1803, fol. 41.

3. Ibídem.

4. GESTOSO Y PÉREZ, José: Sevilla Monumental y Artística. Tomo III, Sevilla, 1897, p. 466.

5. A.B.T.S. Libro de Protocolo. Op. cit., fol. 39.

6. GONZÁLEZ DE LEÓN, Félix: Op. cit., pp. 88-89.

7. GESTOSO Y PÉREZ, José: Op. cit., p. 466. 
motivo central un relieve con el tema iconográfico de las dos Trinidades. En el flanco del evangelio había por entonces dos retablos: uno, el de Jesús ante Anás, antiguo titular de la popular Hermandad de la Bofetá; y otro, el del Sagrado Corazón, hoy desaparecido. A los pies, presidiendo el coro bajo de las religiosas, estaba el retablito de la Virgen del Rosario, actualmente en el coro de niñas. Y, por último, en el lado de la epístola, se situaban el retablo del Cristo del Mayor Dolor, la Dolorosa del Dulce Nombre y San Juan Evangelista; y el retablo de la Virgen del Remedio.

En el coro de las niñas, ubicado al lado de la epístola, junto al presbiterio, presidía el retablito de la Inmaculada. En el costado izquierdo, al igual que hoy, había tres hornacinas con marcos de madera y cristal, pintados de blanco y oro. En su interior se exponían las imágenes de San Luis Gonzaga; una Divina Pastora, de pequeño formato, y San Miguel de los Santos. En el flanco opuesto, tan sólo había una hornacina, semejante a las anteriores, con una escultura de San Juan Bautista de la Concepción. Finalmente, a la derecha del arco de acceso, que por entonces quedaba incomunicado por una reja, había un retablito con la Virgen del Carmen, ahora situada en el antecoro.

En el antecoro, que enlaza el coro de niñas con el claustro principal, había dos pequeñas esculturas sobre sendas mesas. Conforme se entraba desde el claustro, a la izquierda, se exponía un Niño Jesús; y en el ángulo opuesto una imagencita de la Dolorosa, que estaba en depósito. En la actualidad, dicha efigie mariana ha sido retirada por sus propietarios.

\section{A. Reconstrucción de la iglesia y dependencias anexas}

El templo del Beaterio de la Trinidad de Sevilla, que sufrió muy poco durante la República y Guerra Civil, quedó inhabilitado a partir de la riada de 1959. El muro del costado del evangelio se venció y la techumbre a raíz de ello comenzó a calarse con la lluvia. En consecuencia, los retablos ya resentidos quedaron bastante dañados. Por tanto, hubo que clausurar la iglesia, trasladando los cultos a la antigua enfermería.

Ante tal situación, al ser nombrada Superiora del Beaterio, en julio de 1971, Madre Pilar Ormad Morillas se propuso con prioridad restaurar el templo para abrirlo de nuevo al culto público. Con tal motivo, se acometieron las obras que configuraron la actual fisonomía del recinto. En dicha reconstrucción descendió una parte del techo de la nave, desde la cornisa para abajo, quedando así una entreplanta. En ella se dispuso el nuevo coro alto, el archivo o clavería, antes en la planta baja, y un salón. Se picaron y enfoscaron los paramentos de la iglesia. Se sustituyó lo que restaba del antiguo zócalo cerámico por otro de mármol. Se colocó nueva solería del mismo material. Se abrió una ventana donde originaria- 
mente estaba ubicado el retablo del Corazón de Jesús. Y se retiraron las rejas de los coros ${ }^{8}$.

En la Sacristía de los Padres, situada detrás del retablo mayor, se acometieron ciertas mejoras. Se acondicionaron y consolidaron la techumbre, paredes y antiguo zócalo cerámico. Se abrió una puerta donde estaba el torno. Y se habilitó un gran armario y servicio ${ }^{9}$.

En el antiguo coro de las niñas se picaron, enfoscaron y recubrieron de friso sus paredes, dejando libre una franja superior decorada con pintura mural que representa roleos de flores y un ángel. Se colocó un nuevo techo de escayola, se recubrieron los pilares con tabiquería y se acondicionaron los huecos de ventanas y hornacinas. Además, se instaló una puerta de cuarterones de pino holandés con salida al patinillo. Y, por último, se arregló también el antecoro. Allí se puso, al igual que en el coro, una solería de terrazo. Y se alicató con los restos cerámicos del zócalo de la iglesia ${ }^{10}$.

\section{B. Retablos y hornacinas}

En este apartado catalogaremos los distintos retablos y hornacinas de la iglesia, coro, antecoro y sacristía de la misma. Para ello, facilitaremos no sólo el análisis formal e iconográfico de cada obra, sino también cuanto sepamos sobre su historia, remodelaciones y restauros.

\section{B.1. Retablos y hornacinas de la iglesia}

En este subapartado estudiaremos los dos retablos y las tres hornacinas, que se exponen en la iglesia tras la última reordenación litúrgica del espacio. No obstante, haremos las obligadas referencias a los antiguos retablos existentes en el mismo.

\section{B.1.1. RETABLO MAYOR}

Arquitectura en madera tallada y dorada.

Mide: alto, $8,30 \mathrm{~m}$; ancho, $4,45 \mathrm{~m}$.

Obra anónima sevillana.

Principios del siglo XIX (lám. 1).

8. A.B.T.S. Obras realizadas en el edificio del Beaterio de la Santísima Trinidad. siendo Superiora Madre Pilar Ormad Morillas, 1971-1989, notas 22 y 58.

9. Ibídem, nota 23.

10. Ibid., notas 24 y 29 . 
Félix González de León, en 1844, sólo indica que en este “pequeño altar principal se venera la Santísima Trinidad" "'.

Posteriormente, en 1897, José Gestoso amplía la información en los siguientes términos: "El retablo mayor es moderno y sin importancia: en su nicho principal se veneran las efigies esculpidas en alto relieve, en el siglo pasado, de la Sacra Familia bendecida por el P. Eterno, cuya figura, que nos parece más moderna que las otras, se ve entre nubes en la parte superior. A los lados, colocadas en repisas, hay dos efigies faltas de mérito de San Félix de Valois y San Juan de Mata. En el cuerpo segundo se venera un grupo con figuras de tamaño académico, de la Piedad, y a los lados San Francisco y San Antonio, esculturas que tampoco ofrecen interés" ${ }^{12}$.

Dicho retablo ha llegado hasta nuestros días con pequeñas variantes. Se compone de un banco o predella, cuerpo principal y ático semicircular. En el centro del banco hay un magnífico sagrario de plata que sustituyó al original de madera en 1976. Dicha pieza de orfebrería sevillana fue realizada aquel mismo año por Manuel Seco Velasco ${ }^{13}$. Sobre el sagrario monta el expositor. Y, en los extremos abren sendas puertas de medio punto, decoradas con rocallas, que comunican con la sacristía. La situada en el lado del evangelio se abrió en las reformas acometidas en el templo entre 1971-1974, en el lugar que ocupaba el antiguo comulgatorio ${ }^{14}$. Entre estas puertas se dispone adosada la antigua mesa de altar. La frontalera, flanqueada por columnas salomónicas pareadas, presenta un tondo central con la cruz trinitaria entre los emblemas de Jesús y María. Dos ángeles flanquean el sagrario. Son dos esculturas de pasta, seriadas. Uno, a la derecha, vestido de rosa, mide $0,39 \mathrm{~m}$. El otro, a la izquierda, vestido de azul, mide $0,41 \mathrm{~m}$. de alto. Ambos están arrodillados sobre cojines rojos y adoptan una actitud reverencial ante el tabernáculo.

El cuerpo principal está presidido por un sugestivo relieve de las dos Trinidades, tema iconográfico hoy en desuso. Este altorrelieve de medio punto está enmarcado por dos columnas, con fuste estriado y capitel compuesto, y por un entablamento cuyo friso está tachonado de rosetas.

En los laterales, sobre sendas repisas, se exponen, al lado del evangelio, San Juan de Mata y, al lado de la epístola, San Félix de Valois. Debajo de ellos, antiguamente, había dos cuadros con el Corazón de Jesús y el de María, respectivamente. En la actualidad, ambas pinturas se exponen en la biblioteca de la

11. GONZÁLEZ DE LEÓN, Félix: Op. cit., p. 99.

12. GESTOSO Y PÉREZ, José: Op. cit., p. 466.

13. GONZÁLEZ GÓMEZ, Juan Miguel y José María MORILLAS ALCÁZAR: "La Orfebrería del Beaterio de la Trinidad de Sevilla: Morfología y Simbolismo", en Homenaje a D. Dionisio Ortiz Juárez. Córdoba, 1991 (en prensa).

14. A.B.T.S. Obras realizadas siendo Superiora Madre Pilar Ormad Morillas..., nota 23. 
comunidad. En la última remodelación del retablo, en 1975, el artífice sevillano Montero talló el exorno vegetal que presenta en la actualidad.

Especial mención, por su interés iconográfico, merece el relieve principal de las dos Trinidades. En la línea de tierra aparece la Sagrada Familia. La Virgen mide $1,64 \mathrm{~m}$. de alto. Viste túnica turquesa estampada con florecillas doradas y manto azul, también floreado en oro, con vueltas moteadas. Una y otra prenda se enriquecen con fimbrias doradas. La túnica se ajusta a la cintura con áurea lazada. Cubre su cabellera con una toca marfileña de tela encolada e inclina la cabeza hacia la izquierda. La mano derecha reposa sobre el pecho, en inmaculado gesto, y la otra se dirige hacia el Niño Jesús. Bajo el borde inferior de la túnica asoman los zapatos negros. Su rostro parece cobrar vida gracias a sus ojos de cristal, matizados por las pestañas postizas. Sobre sus sienes exhibe una corona de plata de ley, compuesta por un canasto con bandas imperiales y el consabido resplandor rematado con la Cruz. Esta pieza de orfebrería es de marcado sabor decimonónico.

En el otro lado aparece San José en actitud contrapuesta y equilibrada. Mide $1,70 \mathrm{~m}$. de alto. Al igual que su esposa, anuda la túnica, color berenjena, con un lazo de oro. La estampación floral del tejido y las fimbrias son también doradas. Sobre sus hombros muestra un amplio manto abrochado en la base del cuello. Esta prenda, como es usual en la iconografía del santo, es de tonos marrones enriquecida también con estampación floral de oro. Sobre su cabeza, de cabellera oblonga, hay un resplandor de plata del ochocientos. En su mano izquierda, haciéndose eco de los evangelios apócrifos, porta una vara de azucenas de plata ${ }^{15}$. Y su diestra se dirige hacia el Niño Jesús.

El Niño Jesús, exento, mide $0,90 \mathrm{~m}$. de alto. Viste túnica azul francés, estampada con flores cuadrifolias, y lazada de oro a la cintura. El manto, abrochado sobre el pecho, es de color rojo estampado a juego. Inclina la cabeza hacia la derecha y mira hacia lo alto expectante. Bendice con la diestra y en la mano izquierda porta un cetro de plata, símbolo de su infinito poder. Sobre su cabeza hay un resplandor argenteo sin punzón, obra de orfebrería del siglo XIX. Calza sandalias al igual que San José.

Los rostros de las figuras precedentes carecen de la delicadeza emocional de siglos anteriores, aunque mantienen en tono menor la idealización de las formas. Las carnaciones de la Virgen y San José son cálidas y las del Niño más sonrosadas. La Sagrada Familia con el pequeño Jesús itinerante se asocia a la llamada Trinidad terrestre. Sin embargo, la Trinidad celeste corresponde a la Santísima Trinidad. Una y otra se unen en la figura del Niño Jesús. Por eso, en este relieve,

15. SANTOS OTERO, Aurelio de: Los Evangelios Apócrifos. Protoevangelio de Santiago IX. Madrid, 1985, p. 152. GONZÁLEZ GÓMEZ, Juan Miguel: El Belén y la Cartuja de Sevilla a fines del siglo XVIII. Sevilla, 1989, p. 17. 
sobre la cabeza del Hijo aparece el Paráclito radiante. La paloma es blanca y dorada. Y más arriba asoma el Padre Eterno, que viste túnica dorada con estampación floral y moteado semejante al de la indumentaria josefina. Su manto rojo, alistado en oro, es signo de su poder soberano. Con la mano derecha bendice y con la otra sostiene la bola del mundo con la cruz de la salvación. Las nubes plateadas, que le enmarcan semicircularmente, aluden al rompimiento de gloria. Actualmente, esta escena de las dos Trinidades, tan propia del gusto barroco, ha decaído bastante en la iconografía sagrada ${ }^{16}$.

En las repisas laterales se exponen dos esculturas, en madera policromada. Se trata de los dos fundadores de la Orden Trinitaria, dedicada a la redención de cautivos. Al lado del evangelio está San Juan de Mata en marcado contrapposto. Viste el hábito de la Orden. Sobre el escapulario se plasma la cruz trinitaria, cuyo origen se remonta a la celebración de su primera misa, el 28 de enero de 1193. En ese momento le inspiró el Señor la fundación de la Orden de la Santísima Trinidad. Experimentó la visión de un ángel vestido de blanco con una cruz azul y roja sobre el pecho, que ponía su mano sobre unos esclavos encadenados. De esta manera, se justifica dicha insignia y se consolida el objetivo básico y fundamental de la Orden: la liberación y rescate de cautivos ${ }^{17}$.

En la mano izquierda porta un libro de pastas rojas y sobre él una pequeña iglesia, símbolos de las reglas y la Orden por él fundada. En la diestra exhibe una banderola blanca con la cruz trinitaria. La imagen de este sacerdote provenzal, emparentado con una familia condal catalana, mide $1,10 \mathrm{~m}$. de alto ${ }^{18}$. Y puede fecharse en la época del retablo.

Sobre la repisa del lado de la epístola se expone San Félix de Valois, cofundador de la citada Orden, también en acentuado contrapposto. Viste el hábito trinitario, inclina la cabeza hacia la derecha y muestra la tonsura regular y la barba bífida, que a diferencia del anterior, es canosa. Sobre su testa muestra un resplandor de plata de ley. En la diestra porta, como atributo personal, unos grilletes alusivos a la redención de cautivos ${ }^{19}$. Y en la otra mano exhibe un Crucificado. Esta escultura mide 1,12 m. de alto. Y puede datarse en la misma fecha que la anterior.

El ático semicircular está presidido por una hornacina flanqueada por dos columnas corintias cuyo fuste presenta el tercio inferior acanalado. Sobre ellas resplandece un sol con el trigrama de Jesús, procedente del retablo lateral del Calvario. Los dos angelotes semidesnudos, sedentes, sobre el entablamento del cuerpo inferior portaban en origen sendas lámparas. Por el contrario; tras la

16. GONZÁLEZ GÓMEZ, Juan Miguel: El monasterio de Santa Clara de Moguer. Sevilla, 1978, p. 153.

17. VILLOSLADA, Ricardo: Historia de la Iglesia católica. Edad Media (800-1303). Tomo II. Madrid, 1953, p. 723.

18. FERRANDO ROIG, Juan: Iconografía de los Santos Barcelona, 1950, p. 160

19. Ibídem, p. 110. 
remodelación efectuada entre 1971-1974, dichas lámparas fueron sustituidas por antorchas de factura moderna. En el interior de la hornacina central del ático, desde la referida remodelación del retablo, se ubica un Corazón de Jesús que sustituyó al antiguo grupo escultórico de la Piedad en 1974. Las antiguas imágenes de San Francisco y San Antonio, que la flanqueaban, eran de papelón. Ambas han desaparecido. En la actualidad sólo se conserva el Niño Jesús que portaba entre sus brazos San Antonio de Padua.

Este Corazón de Jesús mide $1,40 \mathrm{~m}$. de alto. Es una imagen de pasta de madera cuyo sello dice: "EL ARTE CRISTIANO. OLOT". Procede de un antiguo retablo, situado a la derecha de la puerta exterior de la iglesia, en el flanco del evangelio. En ese lugar se abrió, en 1974, una ventana para iluminar aquel sector del templo. Los dos ángeles genuflexos, de madera y telas encoladas, que flanquean al Corazón de Jesús, en el interior de su hornacina, miden $0,50 \mathrm{~m}$. de alto. Estas dos figuras proceden también del desaparecido retablo del Corazón de Jesús.

El alta mayor, cuyo programa iconográfico original se ha alterado, carece ahora de las citadas representaciones del Corazón de Jesús y de María y de San Francisco de Asís y de San Antonio. Estos santos eran de gran devoción en la comunidad, ya que como se sabe la fundadora tomó el hábito de la Orden Tercera Franciscana en $1725^{20}$. En definitiva, este retablo puede catalogarse como obra anónima sevillana de principios del siglo XIX, pues documentalmente consta que a partir de 1802 D. Bartolomé Cabello construyó la capilla mayor, el coro y las sacristías del templo que nos ocupa ${ }^{21}$. Dicho retablo presentaba originalmente el fondo pintado en color madera y las tallas en dorado. Como es sabido, se estropeó en la riada de 1959. Razón por la que al ser restaurado entre 1971-1974 quedó totalmente dorado y enriquecido con nuevas tallas.

Delante del altar sobre el pavimento del presbiterio hay una lápida de mármol blanco que reza así: "D.O.M. AQUI YACE EL SR. BF. DN. BARTOLOME CABELLO, PRESBYTERO RACIONERO DE LA S. YGLESIA PATR. DE SEVILLA, PREDICADOR INSIGNE, CARITATIVO PADRE Y PROTECTOR DE HUERFANOS Y DESVALIDOS, VISITADOR, DIRECTOR Y RESTAURADOR DE ESTE BEATERIO. MURIO, ADORNADO DE VIRTUDES, EL DIA 5 DE DIZIEMBRE DEL AÑO 1810, A LOS 72 DE SU EDAD R.I.P.A."

En el centro del presbiterio está la nueva mesa del altar, exenta, realizada con fragmentos de los antiguos retablos del templo, desaparecidos en la remodelación efectuada entre 1971-1974. Se decora con columnillas salomónicas a juego con los maceteros que se exhiben en la capilla mayor. Todas estas piezas litúrgi-

20. LEAL ESTUDILlo, M.: Historia del Cuerpo y Alma. Sevilla, 1974, p. 76. ROS, Carlos: Madre Isabel, fundadora del Beaterio de la Trinidad de Sevilla. Sevilla, 1982, p. 120.

21. A.B.T.S. Libro de Protocolo. Op. cit., fol. 39. 
cas, así como un antiguo banco del siglo XIX, decorado con rocallas y patas de garras, aparecen completamente doradas.

El exorno escultórico de la capilla mayor se completa con dos ángeles lampareros, esculturas en madera policromada de $1,05 \mathrm{~m}$. de alto. Visten túnicas verdes floreadas en tonos multicolores y blusones con vueltas voladas, de color rojo rameado en oro. Las alas doradas acentúan el carácter celeste de estos personajes. Calzan borceguíes verde y oro. Y la cabellera volada enmarca el rostro de tez morena, quizás a consecuencia de los repintes y el viraje del barniz.

\section{B.1.2. HORNACINA DE NTRO. PADRE JESUS ANTE ANAS}

Arquitectura en madera tallada y policromada.

Mide: alto, 3,04 m.; ancho, $2 \mathrm{~m}$.

Obra anónima sevillana, remodelada en 1974 por Montero.

Principios del siglo XIX.

En el flanco del evangelio, próximo al presbiterio, se situaba el antiguo retablo de este Cristo Cautivo. Dicho ejemplar estaba policromado en blanco y oro, al igual que el resto de los retablos de la iglesia. Se componía de un banco, cuerpo principal y ático. La hornacina central, destinada al titular del retablo, quedaba protegida por una cristalera. En las repisas laterales se exponían dos esculturas: un Corazón de Jesús y un Corazón de María. Actualmente estas imágenes de serie, de principios del siglo $\mathrm{XX}$, se exponen en la portería del Beaterio. Una y otra conservan, en la base, un sello que dice: "LIBRERIA RELIGIOSA GALLEGOS 19. MANUEL MACIA, SUCESOR DE BAYO. SEVILLA. ARTICULOS DE ESCRITORIO".

Y más arriba había dos pequeñas esculturas de la Virgen del Carmen y de San José. De ellas sólo se conserva la del Patriarca, actualmente expuesta en la capilla, recientemente habilitada en la antigua celda de la fundadora ${ }^{22}$. La decoración escultórica del retablo se completaba con cuatro ángeles mancebos, pasionarios, que hoy posee la Hermandad de La Bofetá, obras de Francisco Antonio Gijón.

Tras la riada de 1959 dicho retablo quedó gravemente dañado. Razón por la que en 1974 fue sustituido por la actual hornacina, recompuesta con elementos del anterior retablo a los que se añadieron las dos semicolumnas laterales, con el tercio inferior acanalado y capitel compuesto. Estas semicolumnas proceden del desaparecido retablo del Corazón de Jesús. El conjunto tectónico se corona con un penacho, original, decorado con la cruz trinitaria. La policromía también fue transformada. El fondo es rojo pompeyano y las tallas doradas.

22. A.B.T.S. Obras realizadas en el edificio del Beaterio de la Stma. Trinidad, siendo superiora Madre Pilar Ormad Morillas. Op. cit., notas 14 y 47. 


\section{B.1.3. HORNACINA DE LA PIEDAD}

Arquitectura en madera tallada y policromada.

Mide: alto, 3,65 m.; ancho, 2,78 m.

Obra anónima sevillana, remodelada en 1974 por Montero y enriquecida con nuevas tallas en 1990 por Rogelio González.

Primera mitad del siglo XVIII.

Originalmente, en su lugar había una hornacina con la Virgen del Rosario, que ahora se expone en el antiguo coro de niñas. Dicha hornacina se complementaba con una pequeña mesa de altar adosada al muro. Este altarcito presidía el coro bajo de las religiosas, de cuya sillería sólo restan dos sitiales, de sencilla factura lignea. Cuando se habilitó el templo para celebrar el II Centenario de la muerte de Madre Isabel, se hizo el nuevo enmarque de la hornacina para el grupo escultórico de la Piedad. Dicho enmarque arquitectónico se configuró con fragmentos de los antiguos retablos del Cautivo y de la Virgen del Remedio. En este sentido, se compone de un arco deprimido o rectilíneo, flanqueado por columnas salomónicas con racimos de uvas y hojas de vid, y rematado con perinolas y penacho central. Todo el conjunto está decorado en verde y oro. En 1990 se colocó el cristal que cierra la hornacina y las dos molduras doradas de las enjutas, obra realizada ese mismo año por Rogelio González.

El grupo escultórico de la Piedad se trasladó desde el ático del retablo mayor hasta este emplazamiento, ya que en este lugar, sobre el pavimento, está enterrada la fundadora del Beaterio. La lápida de mármol blanco dice así: "DEPOSITO DE LOS HUESOS DE LA MADRE ISABEL DE LA STMA. TRINIDAD, FUNDADORA DE ESTE BEATERIO DEL MISMO NOMBRE, NATURAL DE SEVILLA, DE LA PARROQUIA DE S. GIL, DONDE NACIO EN 22 DE MAYO DE 1693. DOTADA POR EL SEÑOR DE UNA ALMA GRANDE, QUE PROCURANDO SU GLORIA POR LA SANTIFICACION DE LAS NIÑAS DESVALIDAS A COSTA DE AFANES Y TRABAJOS, LOGRO ABRIR ESTA FUNDACION EL AÑO DE 1724 Y LLEVANDO ADELANTE SU EMPEÑO EN MEJORARLA HIZO DOS VIAJES A LA AMERICA, EN EL REINO DE NUEVA ESPAÑA, Y CON LAS LIMOSNAS QUE REUNIO ADELANTO CUANTO PUDO ESTA OBRA SIN LLEGAR A LO QUE ANHELABAN SUS DESEOS. MURIO ENTRE SUS AMADAS HIJAS EN 8 DE MAYO DE 1774. FUE SEPULTADA, POR NO ESTAR BENDITA SU IGLESIA, EN LA PARROQUIA DE STA. LUCIA, HABIENDO DISPUESTO QUE SU CADAVER SE TRASLADASE DESPUES A ESTA SU CASA A LO QUE SE EJECUTO EL DIA 16 DE AGOSTO DE 1828, CON LAS FORMALIDADES DEBIDAS. LA MEMORIA DE SU CARIDAD SEA ESTIMULO PARA ENCENDER LA DE SUS HIJAS. R.I.P.A." 


\title{
B.1.4. RETABLO DEL CALVARIO
}

\author{
Arquitectura en madera tallada y policromada. \\ Mide: alto, 3,85 m.; ancho, $2,87 \mathrm{~m}$. \\ Obra anónima sevillana, remodelada en 1974 por Montero. \\ Principios del siglo XIX.
}

En el flanco de la epístola, próximo a la pequeña puerta que comunica la nave de la iglesia con el claustro, se conserva el antiguo retablo del Calvario, al que únicamente se ha desposeído de su mesa de altar adosada y del sol que coronaba el conjunto. Como sabemos, dicho sol es el que hoy ostenta el retablo mayor. La hornacina central, acabada en testero plano, se revistió en 1974 con una plancha de formica que imita mármol verde jaspeado. Dicha hornacina de medio punto, flanqueada por pilastras de fuste acanalado, presenta en las enjutas decoración vegetal y frutos. En origen, este retablo, de formato muy clásico, estaba pintado en blanco y dorado, a juego con el resto de los retablos laterales del templo. No obstante, desde 1974 está decorado en rojo pompeyano y oro.

\section{B.1.5. HORNACINA DE LA VIRGEN DEL REMEDIO}

Arquitectura en madera tallada y policromada.

Mide: alto, $3,04 \mathrm{~m}$.; ancho, $2 \mathrm{~m}$.

Obra anónima sevillana, remodelada en 1974 por Montero.

Principios del siglo XIX.

A continuación está la hornacina de la Virgen del Remedio, idéntica a la frontera consagrada al Cautivo. Se compone de un arco de medio punto entre dos semicolumnas adosadas, con capitel compuesto y fuste con el tercio inferior acanalado. El total resultante está rematado por un penacho procedente del antiguo retablo de esta Virgen, en cuya cartela central campea la cruz trinitaria. Por el contrario, las semicolumnas pertenecieron al desaparecido retablo del Corazón de Jesús. En la remodelación de 1974 se entonó todo el conjunto tectónico combinando el rojo pompeyano y el oro.

\section{B.2. Hornacinas del coro bajo}

En el coro bajo, llamado de las niñas, abierto en el costado de la epístola, hay cinco hornacinas. Preside una, de medio punto, con la Inmaculada, cuyo enmarque arquitectónico ha sido recientemente dorado. Mide $1 \mathrm{~m}$. de alto y $0,61 \mathrm{~m}$. de ancho. En origen contaba con su correspondiente mesa de altar adosada al muro. Ahora ésta ha sido sustituida por una consola dorada ${ }^{23}$. De las cuatro hornacinas

23. Ibídem, nota 24. 
restantes hay tres en el costado izquierdo. De estas tres, la central de medio punto, mide $1,44 \mathrm{~m}$. de alto y $0,84 \mathrm{~m}$. de ancho. Y las laterales, de orejetas, miden $1,40 \mathrm{~m}$. de alto y $0,83 \mathrm{~m}$. de ancho. La del flanco derecho, también de medio punto, mide $1,87 \mathrm{~m}$. de alto y $1,05 \mathrm{~m}$. de ancho. Todas presentan un escueto formato, sólo ostentan un sencillo marco de madera, pintado en blanco, con su correspondiente cristal. En su interior se exponen las esculturas de San Luis Gonzaga, la Virgen del Rosario, San Miguel de los Santos y San Juan Bautista de la Concepción, respectivamente. Todo el conjunto respira un profundo sabor decimonónico, época en que fue labrada y decorada esta dependencia eclesiástica.

\section{B.3. Retablos del antecoro}

En el antecoro, que comunica el coro bajo con el claustro del Beaterio, se conservan dos interesantes urnas sobre sendas mesas de altar. Una de ellas está dedicada a la Dolorosa, mide $1,35 \mathrm{~m}$. de alto y $0,96 \mathrm{~m}$. de ancho, y la otra, la de la Virgen del Carmen, mide $2 \mathrm{~m}$. de alto y $0,88 \mathrm{~m}$. de ancho.

\section{Esculturas del Beaterio de la Trinidad}

En este apartado analizaremos las esculturas de la iglesia, coro bajo, antecoro y sacristía del Beaterio de la Trinidad de Sevilla. Cronológicamente abarcan desde el siglo XVII al XX.

\section{C.1. Esculturas de la iglesia}

En la iglesia del Beaterio se exponen seis esculturas a excepción de las del retablo mayor, ya analizadas. Todas ellas se ubican en sus altares y hornacinas. En el flanco del evangelio se sitúa Jesús ante Anás, en su hornacina correspondiente. A los pies se encuentra la hornacina en la que actualmente se da culto al grupo escultórico de la Piedad. En el flanco de la epístola se dispone el retablo del Calvario, con el Crucificado, la Virgen del Dulce Nombre y San Juan Evangelista, las dos últimas antiguas titulares de la Hermandad de La Bofetá. Y, para terminar, en este mismo flanco se encuentra la Virgen del Remedio, en su hornacina semejante a la de Jesús ante Anás. 


\section{C.1.1. NUESTRO PADRE JESUS ANTE ANAS}

Escultura en pasta y madera policromada para vestir.

Mide $1,65 \mathrm{~m}$. de alto.

Obra anónima sevillana.

Primer tercio del siglo XVII (lám. 2).

Se trata del antiguo titular de la Fervorosa e Ilustre Hermandad y Cofradía de Nazarenos de Nuestro Padre Jesús ante Anás, Santo Cristo del Mayor Dolor y Dulce Nombre de María, fundada en el Hospital de Niñas Huérfanas de la Magdalena. Documentalmente nos consta que en 1732 esta cofradía, vulgo de $L a$ Bofetada, ya estaba extinguida en dicho centro de beneficencia. Textualmente se aclara que las hermandades extinguidas no salían todos los años; "unas salen unos años y otras otros; por el coste y ser algunas pobres" ${ }^{24}$. Efectuó su última estación de penitencia en 1745. Y en 1809 las imágenes titulares fueron trasladadas al Beaterio de la Santísima Trinidad ${ }^{25}$.

Posteriormente, en 1919, renovada esta Hermandad penitencial, recuperó sus primitivas imágenes titulares que procesionaron en 1920. Al año siguiente encargaron al escultor Angel Rodríguez Magaña un nuevo misterio que no agradó a los cofrades. Por ello, en 1923, Antonio Castillo Lastrucci realizó el actual. Razón por la que las antiguas titulares, excepto el Crucificado del Mayor Dolor y los ángeles mancebos del paso Cristo, retornaron a la iglesia del Beaterio de la Trinidad ${ }^{26}$.

La escultura que nos ocupa, muy remodelada a través del tiempo, responde al modelo iconográfico del Cautivo, profundamente ligado a la Orden Trinitaria. Fr. José Alvarez de la Fuente, en su obra Sucesión Pontificia... publicada en Madrid en 1746, se hace eco de una crónica de la Orden Trinitaria. Según dicha crónica, Felipe III, para combatir a los berberiscos, envió tropas al mando de D. Luis Fajardo para tomar Mámora, ciudad próxima a Argel. Ultimada la conquista, la mezquita fue transformada en templo cristiano. Precisamente, en aquel templo colocaron al culto varias imágenes, entre las cuales había una de Jesús Nazareno.

Al ser reconquistada, muchos años después, dicha población por los musulmanes, los frailes trinitarios comenzaron a negociar en Fez el rescate del Nazare-

\footnotetext{
24. (B)iblioteca (C)apitular (C)olombina (S)evilla. Ms 83-4-19. Noticia Compendiosa de los Templos de Sevilla y demás cosas curiosas de ella, s/f. MORILLAS ALCÁZAR, José María: La Entrada Triunfal de Felipe $V$ en Sevilla. Trabajo de Investigación presentado en la Universidad de Sevilla el 18 de julio de 1990.

25. GONZÁLEZ DE LEÓN, Félix: Noticia artística, histórica y curiosa de todos los edificios públicos, sagrados y profanos de esta M.N. y M.L. e invicta ciudad de Sevilla. Sevilla, 1844, pp. 98-99; IDEM: Historia crítica y descriptiva de las Cofradias de penitencia, sangre y luz, fundadas en la ciudad de Sevilla. Sevilla, 1852, p. 17. GONZÁLEZ GÓMEZ, Juan Miguel: "Un ejemplo del mecenazgo americano en Sevilla: El Beaterio de la Trinidad" en Rev. Laboratorio de Arte n. ${ }^{9}$ 3. Sevilla, 1990, p. 102.
}

26. CARRERO RODRÍGUEZ, Juan: Anales de las Cofradias de Sevilla. Sevilla, 1984, pp. 209-210. 
no. Los infieles, tras poner múltiples inconvenientes, decidieron entregar la imagen si los religiosos abonaban por ella su peso en monedas de oro. Una vez firmado el convenio, se colocó la escultura en un platillo de la balanza y, al comenzar los frailes a depositar monedas en el otro, éste se inclinó rápidamente como si el peso fuese muy leve. El prodigio se repitió cuantas veces cambiaron la balanza.

Los moros ensoberbecidos por su impotencia ante la omnipotencia de Dios, arrojaron la escultura a una hoguera. Extinguido el fuego, el Cristo había quedado sin la más leve quemadura. Entonces, encerraron la imagen del Redentor, como un cautivo vulgar, en un oscuro calabozo. De inmediato se declaró en la población una terrible peste. Aterrados, los marroquíes sacaron dicha efigie y, a través de Argel, Mojador y Tánger, la entregaron a los españoles, que acto seguido la embarcaron de nuevo a España.

De esta forma, los trinitarios trasladaron el Cristo a Madrid, poniéndolo, como el cuerpo de San Francisco de Borja, bajo el patrocinio de los duques de Medinaceli. Ante tal acontecimiento, la Orden Trinitaria, dedicada a la redención de cautivos, dispuso que una imagen de ese modelo iconográfico se expusiera al culto en todos los conventos trinitarios descalzos del mundo ${ }^{27}$.

Nuestro Padre Jesús ante Anás, antiguo titular de la cofradía sevillana de la Bofetá, con las manos atadas ante el pecho, viste túnica morada, color de sufrimiento y penitencia ${ }^{28}$. El rostro, poco expresivo, presenta ojos pintados y pestañas postizas. La cabellera de menudos rizos, al gusto manierista, ostenta posteriores aditamentos de estopa. Sobre su testa hay tres potencias de plata, de rayos agudos y flameantes, que, en la humanidad deshecha de Cristo, significan la plenitud de gracia, de ciencia y de poder ${ }^{29}$. Este simulacro, de escaso valor artístico, fue restaurado por Angeles Gutiérrez para procesionar el Martes Santo de $1920^{30}$. Y hace pocos años, Adolfo Castillo y José Pérez lo repolicromaron y afianzaron con motivo de figurar en La Semana Santa del ayer, exposición organizada por la Caja San Fernando de Sevilla en $1985^{31}$.

\footnotetext{
27. Estos datos nos han sido facilitados por nuestro buen amigo y compañero D. Bibiano Torres Martín.

28. FERGUSON, George: Signos y simbolos en el arte cristiano. Buenos Aires, 1956, p. 219.

29. GONZÁLEZ GÓMEZ, Juan Miguel: "Iconografía del Nazareno procesional en Sevilla", en Actas del Congreso Internacional Cristóbal de Santa Catalina y las Cofradías de Jesús Nazareno. Córdoba, 1991. tomo II, p. 698.

30. CARRERO RODRÍGUEZ, Juan: Op. cit., p. 209.

31. CARRERO RODRÍGUEZ, Juan; La Semana Santa del ayer. Catálogo. Sevilla, 1985, p. 60. RODA PEÑA, José: "Antiguas imágenes titulares de las Cofradías sevillanas", en Las Cofradias de Sevilla en el siglo de las crisis. Sevilla, 1991, p. 216.
} 


\section{C.1.2. PIEDAD}

Grupo escultórico en madera y pasta policromada.

Mide $0,87 \mathrm{~m}$. de alto.

Obra anónima sevillana.

Siglos XVII-XVIII (lám. 3).

Al atardecer del día 24 de octubre de 1722, terminadas las obras del Beaterio de la calle Enladrillada, salió de la parroquia de San Gil la Hermandad del Rosario. Y trasladaron, en devota procesión, la Virgen de los Dolores, propiedad de Madre Isabel, hasta el nuevo asilo de niñas huérfanas ${ }^{32}$. Desde allí, pasó el 8 de diciembre de 1728 a la nueva sede de la calle de Santa Lucía ${ }^{33}$. Ampliada la iglesia por D. Bartolomé Cabello, párroco de Santa María la Blanca y prebendado de la catedral de Sevilla, se expuso a principios del siglo XIX en el ático del retablo mayor ${ }^{34}$. Por último, tras la reforma acometida por la actual Superiora del Beaterio, Madre Pilar Ormad Morillas, entre 1971-1974 se ubicó al final de la iglesia, sobre el enterramiento de la fundadora ${ }^{35}$.

Tras el grupo escultórico de la Piedad aparece el madero. En el extremo superior del stipes se fija el INRI. El sudario pende del patibulum de la cruz, sobre el que se apoyan las dos escaleras. Sobre un monte de peñascos hay un cojín de damasco rojo en el que se expone el cadáver de Cristo. Detrás, la Virgen contempla al Hijo martirizado, requiriendo compasión y piedad en su dolor.

La figura del yacente, de papelón, en pose cadavérica, presenta facies hipocrática, manchas hipostáticas, etc. El paño de pureza, muy bajo, se anuda en la cadera derecha con moña y larga caída, al gusto manierista. La barba y cabellera, minuciosamente trabajadas, insisten en la estética de hacia 1600 . Sobre su testa despuntan las potencias de plata, como una corrupción del nimbo cruciforme que simboliza la redención mediante la Cruz ${ }^{36}$.

La Virgen de los Dolores, imagen de candelero para vestir, responde a una estética más evolucionada. Su indumentaria se compone de saya y manto de terciopelo negro, tocado de tul y toca de sobremanto de encaje. En su pecho hay un puñal de plata que sintetiza los siete dolores que fueron traspasando su alma en la profecía del Santo Simeón, en la huida a Egipto, en la pérdida de Jesús en el Templo, en la calle de la Amargura, en la crucifixión del Señor, en el descendimiento y en la sepultura de Cristo ${ }^{37}$. Y sobre sus sienes, como Reina del dolor,

32. LEAL ESTUDILLO, M.: Historia de Cuerpo y Alma. Sevilla, 1974, pp. 29 y 76.

33. ROS, Carlos: Madre Isabel, fundadora del Beaterio de la Trinidad de Sevilla. Sevilla, 1982, pp. 44 y 120.

34. A.B.T.S. Libro de Protocolo. Op. cit., fol. 39.

35. A.B.T.S. Obras realizadas en el edificio del Beaterio de la Santísima Trinidad, siendo Superiora Madre Pilar Ormad Morillas. 1971-1989. Op. cit.

36. FERGUSON, George: Signos y símbolos en el arte cristiano. Buenos Aires, 1956, p. 222.

37. GONZÁLEZ GÓMEZ, Juan Miguel y Manuel Jesús CARRASCO TERRIZA: Escultura Mariana Onubense. Huelva, 1981, p. 214. 
se ajusta una esplendente corona de plata, con canasto y resplandor rematado con cruz vegetal. Esta pieza de orfebrería se decora con rocallas decadentes, propias del ochocientos.

La Dolorosa presenta la mascarilla y manos talladas en madera. En su estructura lignaria interior, los brazos no están articulados. El rostro tiene el óvalo alargado y enjuto. Los ojos de cristal han perdido las pestañas postizas, aunque conservan el peleteado de los párpados inferiores. Las cejas, fruncidas y descendentes, acentúan la aflicción del semblante. La nariz rotunda mantiene un cierto clasicismo. La boca, de labios finos y entreabiertos, dejan ver los dientes superiores y la lengua. Las carnaciones, rosadas muy pálidas, recuerdan las entonaciones aporcelanadas dieciochescas. Por sus mejillas resbalan lágrimas de cristal, tres por cada lado. Por último, debemos reparar en las manos, de palmas anchas y dedos largos que se flexionan a partir de la segunda falange. Cuanto expuesto queda nos hace pensar que esta imagen es posterior a la del Cristo yacente; o bien, que fue profundamente remodelada en el siglo XVIII.

\section{C.1.3. CRUCIFICADO}

Escultura en madera policromada.

Mide 1,72 m. de alto.

Obra anónima valenciana.

Hacia 1919 (lám. 4).

Al reorganizarse en 1919 la Hermandad de Nuestro Padre Jesús ante Anás, Santo Cristo del Mayor Dolor y Dulce Nombre de María, retiraron del Beaterio de la Trinidad las antiguas titulares que desde 1809 residían allí, procedentes del Hospital de Niñas Huérfanas de la Magdalena. En 1924, tras realizar las nuevas esculturas Castillo Lastrucci, fueron devueltas a su lugar de origen ${ }^{38}$. Sin embargo, la renovada corporación retuvo en su poder el Santo Cristo del Mayor Dolor y los cuatro ángeles mancebos del paso, atribuidos a Francisco Antonio Gijón ${ }^{39}$. Por entonces debió sustituirse el magnífico Crucificado por el actual.

El Cristo del Mayor Dolor, de 1,40 m. de alto, está catalogado como obra atribuida a Juan de Oviedo y de la Bandera hacia $1600^{40}$. Procesionó hasta 1745 , aunque ignoramos si lo hacía solo o formando un Calvario con la Virgen del Dulce Nombre y San Juan Evangelista ${ }^{41}$. En la actualidad, desde 1968, recibe culto interno en la antigua capilla del Gran Poder, en la parroquia sevillana de

\footnotetext{
38. CARRERO RODRÍGUEZ, Juan: Anales de las cofradías sevillanas. Op. cit., p. 210.

39. Ibídem, p. 208. GONZÁLEZ GÓMEZ, Juan Miguel y José RODA PEN̉A: "Imagineros e imágenes de la Semana Santa sevillana (1563-1763)", en Las Cofradias de Sevilla en la modernidad. Sevilla, 1988, p. 239.

40. RODA PEÑA, José: "Antiguas imágenes titulares de las Cofradías sevillanas", en Las Cofradias de Sevilla en el siglo de las crisis. Sevilla, 1991, pp. 200-202.

41. BERMEJO Y CARBALLO, José: Glorias religiosas de Sevilla. Sevilla, 1882, p. 139.
} 
San Lorenzo. En 1985 volvió a procesionar con motivo del IV Centenario de la fundación de la Hermandad.

El Crucificado que ahora compone el Calvario con la Dolorosa y el Evangelista es, pues, obra del primer cuarto del novecientos. Es un Cristo muerto que reclina la cabeza hacia la derecha y hacia adelante. Se fija al madero con tres clavos, cruzando la pierna derecha sobre la izquierda. El paño de pureza, de equilibrada composición, se anuda en la cadera derecha. Sobre sus carnaciones grisáceas destacan las llagas y signos del martirio. El rostro, de pronunciados pómulos y afilada nariz, queda enmarcado por la cabellera, bigote y barbas bífidas. Tiene ojos de cristal. Sobre la testa porta corona de espinas y tres potencias de plata.

\section{C.1.4. MARÍA SANTÍSIMA DEL DULCE NOMBRE \\ Imagen de candelero para vestir en pasta y madera policromadas. \\ Mide $1,63 \mathrm{~m}$. de alto. \\ Obra anónima sevillana. \\ Primer tercio del siglo XVII (lám. 4).}

Es la antigua Dolorosa de la Hermandad de la Bofetada. Por tanto, en 1809 fue trasladada desde la hospitalidad de niñas huérfanas de la Magdalena a la iglesia del Beaterio de la Santísima Trinidad ${ }^{42}$. Reorganizada la Cofradía en 1919, volvió a procesionar en la Semana Santa de Sevilla desde 1920 a $1923^{43}$. Precisamente, en 1922, estacionó bajo el palio de terciopelo azul bordado en oro por Juan Manuel Rodríguez Ojeda. Al año siguiente estrenó el manto bordado sobre el mismo tejido por el referido artista ${ }^{44}$. Y, en 1924 , fue sustituida por la nueva Dolorosa de Castillo Lastrucci ${ }^{45}$. Razón por la que la efigie que analizamos volvió al Beaterio de la Trinidad.

La imagen, muy manipulada a través del tiempo, presenta totalmente alteradas todas sus características morfológicas. Su aspecto amuñecado se debe al burdo repinte de la mascarilla de tonos pálidos con mejillas rosadas. Los ojos de cristal aparecen torpemente hundidos en las cuencas orbitales. Las cejas, de trazado rectilíneo, no siguen el ritmo de la talla. Los labios entreabiertos dejan ver los dientes superiores. La barbilla prominente y la papada configuran un óvalo redondeado. Y por detrás de los pabellones auditivos descienden sendas guedejas de cabello.

\footnotetext{
42. GONZÁLEZ DE LEÓN, Félix: Historia crítica y descriptiva de las cofradías de penitencia, sangre y luz, fundadas en la ciudad de Sevilla. Op. cit., p. 17.

43. CARRERO RODRÍGUEZ, Juan: Anales de las Cofradias de Sevilla. Op. cit., pp. 209-210.

44. Ibídem, p. 210. RODA PEÑA, José: "Antiguas imágenes titulares de las Cofradías sevillanas”. Op. cit., p. 217.

45. CARRERO RODRÍGUEZ, Juan: Anales de las Cofradias de Sevilla. Op. cit., p. 210.
} 
Las manos, bien resueltas, ostentan anchos empeines y dedos suavemente flexionados para portar, como es usual en las Dolorosas sevillanas, el rosario y el pañuelo. Están trabajadas en madera con carnaciones aporcelanadas. Viste saya de terciopelo morado con encajes dorados, dispuestos en bandas paralelas al gusto romántico, manto de brocatel negro y oro, y tocado de encaje. Sobre su testa hay un resplandor de plata.

\section{C.1.5. SAN JUAN EVANGELISTA}

Imagen de candelero para vestir.

Mide $1,76 \mathrm{~m}$. de alto.

Obra anónima sevillana.

Primera mitad del siglo XVII (lám. 4).

San Juan compone el actual Calvario, al pie del Crucificado, junto a María Santísima del Dulce Nombre. Inclina la cabeza hacia la derecha. Su cabellera, de movidas guedejas, enmarca adecuadamente el conjunto. En su rostro, de tez morena, destacan los ojos de cristal matizados por pestañas postizas. El bigote y la perilla refuerzan el vigor varonil de la figura.

Iconográficamente responde al modelo impuesto en la estatuaria sevillana por el San Juan Evangelista del Gran Poder, obra realizada por Juan de Mesa en $1620^{46}$. Viste túnica de terciopelo verde y manto rojo del mismo tejido, colores que, en el simbolismo sagrado, expresan la regeneración del alma mediante las buenas obras y los más puros sentimientos de caridad cristiana, respectivamente ${ }^{47}$. Por el borde inferior de la túnica asoman los pies calzados con sandalias. Y, sobre su cabeza, una aureola acentúa el carácter sacro de la efigie.

Esta imagen, junto con la Dolorosa y Nuestro Padre Jesús ante Anás, antiguas tituläres de la popular Hermandad de La Bofetá, formaron parte de la exposición que, sobre la Semana Santa del ayer, organizó la Caja San Fernando de Sevilla en $1985^{48}$.

\section{C.1.6. VIRGEN DEL REMEDIO}

Imagen de candelero para vestir.

Mide $1,50 \mathrm{~m}$. de alto.

Obra anónima sevillana.

Ultimo tercio del siglo XVIII (lám. 5).

46. GONZÁLEZ GÓMEZ, Juan Miguel y José RODA PEÑA: "Imagineros e imágenes de la Semana Santa de Sevilla". Op. cit., p. 187.

47. GONZÁLEZ GÓMEZ, Juan Miguel: "Sentimiento y simbolismo en las representaciones marianas de la Semana Santa de Sevilla", en Las Cofradías de Sevilla. Historia, Antropología, Arte. Sevilla, 1985, p. 144.

48. CARRERO RODRÍGUEZ, Juan: La Semana Santa del ayer. Op. cit., p. 60. 
La Virgen del Remedio es la patrona de la Orden Trinitaria, porque se apareció a los fundadores y les entregó una bolsa con dinero para redimir cautivos. Viste, pues, el hábito trinitario. Traje y escapulario son de brocatel blanco y oro, con la cruz trinitaria en el pecho. Sobre el manto, de terciopelo azul, destaca la toca de sobremanto de encaje blanco.

Iconográficamente, responde al modelo de la Hodegetria o Virgen Conductora. María aparece, de pie, mostrando al Niño Dios sobre su regazo, como único camino de salvación ${ }^{49}$. El rostro, de amplias facciones, tiene ojos de cristal con pestañas postizas. Y, como es habitual en la imaginería barroca, luce cabellera de pelo natural. La imagen, de nacaradas carnaciones, conserva restos de varias policromías. En su mano derecha exhibe el cetro real, emblema del poder soberano. Su corona, de plata blanca, se compone de canasto con imperiales y resplandor rematado con una cruz calada. Esta pieza de orfebrería, decorada con rocallas decadentes, conserva en la cruceta el punzón "XIMENEZ".

La Virgen del Remedio sostiene, con la mano izquierda, al pequeño Jesús, escultura en madera policromada de $0,43 \mathrm{~m}$. de alto. Está totalmente anatomizado. La cabellera presenta un copete central entre dos movidos mechones. El rostro infantil, de sonrosados mofletes, tiene ojos de cristal con pestañas postizas y boca cerrada. Bendice con la diestra y en la izquierda muestra el globo terráqueo con las bandas de la salvación rematadas por la cruz. Viste traje de raso blanco con encajes, cordoncillo y lentejuelas doradas. Lleva calcetines de hilo blanco calado y zapatos de plata del siglo XIX. La corona, también de plata, tiene el canasto con cuatro imperiales que se unen con la bola del mundo. En la cruceta interior conserva el punzón "GONZAL..". Su decoración, propia del ochocientos, está realizada a base de rocallas y florecillas.

\section{C.2. Esculturas del coro bajo}

En el coro bajo o coro de niñas se exponen al culto, en sus correspondientes hornacinas, seis imágenes que analizaremos seguidamente. En el costado izquierdo están las de San Luis Gonzaga, la Virgen del Rosario y San Miguel de los Santos. En la cabecera, la Inmaculada Concepción. Y en el costado derecho, San Juan Bautista de la Concepción. Para terminar, en el lado izquierdo del arco que da acceso a la iglesia hay una hornacina en cuyo interior se expone a Cristo atado a la columna.

49. GONZÁLEZ GÓMEZ, Juan Miguel y Manuel Jesús CARRASCO TERRIZA: Escultura Mariana Onubense. Op. cit., pp. 136-137. 


\section{C.2.1. SAN LUIS GONZAGA}

Imagen de candelero para vestir.

Mide $0,85 \mathrm{~m}$. de alto.

Obra anónima.

Primera mitad del siglo XIX (lám. 6).

La iconografía de este santo, bastante definida, arranca del siglo XVIII, ya que fue canonizado en 1726. Este joven novicio de los Jesuitas fue miembro de una noble familia italiana. Murió en Roma contagiado por la peste al cuidar a los enfermos ${ }^{50}$.

Viste, como es lógico, sotana negra y sobrepelliz blanca. Inclina la cabeza hacia la izquierda para contemplar el Crucificado que porta en la siniestra. Originalmente debió mostrar en la mano derecha una rama de azucena, símbolo de pureza ${ }^{51}$. Finalmente, una argéntea aureola subraya el carácter sacro del personaje.

\section{C.2.2. VIRGEN DEL ROSARIO}

Imagen de candelero para vestir.

Mide $0,74 \mathrm{~m}$. de alto.

Obra anónima sevillana.

Primer tercio del siglo XIX (lám. 7).

La Virgen del Rosario hasta 1971 presidía, desde un pequeño retablito, el antiguo coro bajo de las religiosas, ubicado a los pies del templo. En aquel lugar hoy se expone al culto la Virgen de los Dolores, de Madre Isabel. A partir de esa fecha se trasladó a la hornacina del coro de niñas, donde se venera en la actualidad, sustituyendo a una pequeña imagen de la Divina Pastora.

La Virgen, de pie, lleva a Jesús Niño sobre el brazo izquierdo. Entre sus manos porta el rosario, invitando a los fieles al ejercicio de tan piadosa práctica que resume los más importantes acontecimientos de la Redención, contemplados desde la óptica de María ${ }^{52}$.

El rostro, de menudas facciones y óvalo redondeado, tiene ojos de cristal con pestañas postizas, cejas arqueadas, nariz afilada y boca de labios finos y cerrados. Según el dictamen estético del barroco, la cabellera es de pelo natural.

Viste saya de raso blanco, manto rojo bordado en oro y toca de sobremanto de encaje blanco. La corona, de plata de ley, procede de otra imagen mariana. Se

\footnotetext{
50. FERRANDO ROIG, Juan: Iconografia de los santos. Op. cit., p. 177.

51. MORALES Y MARÍN, José Luis: Diccionario de Iconología y Simbología. Madrid, 1984, p. 76.

52. GONZÁLEZ GÓMEZ, Juan Miguel y Manuel Jesús CARRASCO TERRIZA: Escultura Mariana Onubense. Op. cit., pp. 483-484.
} 
compone de canasto y resplandor, de rayos agudos y flameantes con estrellas, al gusto del siglo XVII.

El Niño Jesús es una pequeña escultura en madera policromada de 0,17 m. de alto. Bendice con la diestra. Viste túnica blanca bordada en oro. Entre sus manos extiende, al igual que su Madre, el rosario, atributo específico de esta advocación mariana. Sobre su testa exhibe una corona de elevados imperiales que se unen en la bola del mundo rematada por la cruz, símbolo de Redención.

\section{C.2.3. SAN MIGUEL DE LOS SANTOS}

Escultura en madera policromada.

Mide $1,16 \mathrm{~m}$. de alto.

Obra anónima sevillana.

Primer tercio del siglo XIX (lám. 8).

Este santo trinitario descalzo de Vich (1591-1625) destacó por su gran amor a la Eucaristía. Murió a los 33 años. Razón por la que se le representa joven ${ }^{53}$. Viste el hábito de la Orden: túnica y escapulario blancos con fimbrias doradas; áurea muceta; manto y capuchón negros; cruz sobre el pecho, con la faja transversal azul y la otra roja. Luce tonsura monacal y sandalias. Y porta en la diestra una custodia-ostensorio de plata de la segunda mitad del siglo XIX ${ }^{54}$.

La escultura, de equilibrada composición, presenta un marcado contrapposto. El rostro varonil, bien modelado, tiene ojos de cristal y pestañas postizas. La cabeza, provista de su correspondiente resplandor, gira hacia la izquierda para contemplar la Sagrada Forma. De esta manera, se rompe la frontalidad y se introduce un cierto dinamismo en el total resultante.

\section{C.2.4. INMACULADA}

Imagen de candelero para vestir.

Mide $0,73 \mathrm{~m}$. de alto.

Obra anónima sevillana.

Primer cuarto del siglo XIX (lám. 9).

En las reformas realizadas en el antiguo coro de niñas, éntre 1971-1989, se sustituyó la antigua mesa de altar de la Inmaculada por una consola dorada ${ }^{55}$. Esta imagen de la Purísima preside dicha dependencia eclesiástica. Su indumen-

53. FERRANDO ROIG, Juan: Iconografía de los santos. Op. cit., p. 201.

54. GONZÁLEZ GÓMEZ, Juan Miguel y José María MORILLAS ALCÁZAR: "La orfebrería del Beaterio de la Trinidad de Sevilla: morfología y simbolismo. Op. cit.

55. A.B.T.S. Obras realizadas en el edificio del Beaterio de la Santísima Trinidad, siendo Superiora Madre Pilar Ormad Morillas. Op. cit., nota 24. 
taria concepcionista se compone de túnica blanca y manto de raso celeste tachonado de estrellas y orlado de encaje dorado. Sus brazos se cruzan ante el pecho en inmaculado gesto.

La Virgencita, de tostadas carnaciones, posee una abundante cabellera de pelo natural. Detrás hay una gran guirnalda de rosas, concebida a modo de ráfaga, que alude a las virtudes de María ${ }^{56}$. Tanto las florecillas como la ampulosa y movida disposición de las telas obedecen al gusto monjil.

\section{C.2.5. SAN JUAN BAUTISTA DE LA CONCEPCION}

Imagen de candelero para vestir.

Mide $1,60 \mathrm{~m}$. de alto.

Obra anónima sevillana.

Primer cuarto del siglo XIX (lám. 10).

San Juan Bautista de la Concepción (1561-1613) es reformador de la Orden Trinitaria y escritor ascético-místico, comparable a Santa Teresa de Jesús y a San Juan de la Cruz ${ }^{57}$. Nació en Almodóvar del Campo (Ciudad Real) el 10 de julio de 1561. Ingresó en la Orden de los Trinitarios en 1580. Obtuvo de Clemente VIII, el 20 de agosto de 1599, el Breve Ad militantis Ecclesiae regimen por el que se aprueba y erige canónicamente la descalcez trinitaria. Fundó dieciocho conventos de frailes y uno de monjas. Murió en Córdoba el 14 de febrero de 1613. Fue beatificado por Pío VII el 26 de septiembre de 1819 y canonizado por Pablo VI el 25 de mayo de $1975^{58}$.

Juan Bautista de la Concepción muestra el consabido hábito tricolor de la Orden. Porta en la diestra un Crucificado y en la otra mano, una pequeña ermita de plata de hacia $1800^{59}$. Calza sandalias. Tiene ojos de cristal y pestañas postizas. Y lleva resplandor de plata del siglo XIX.

La Cruz de Cristo ocupará el centro de la espiritualidad de este Reformador trinitario. Por un lado, su maestro en el noviciado, el P. Alonso de Rieros, exhortaba a sus novicios a "que jamás pierdan su presencia y vista interior a Cristo crucificado". Por otro, la primera noche que pasa en el convento de Valdepeñas, el 14 de febrero de 1597, tiene una visión especial. Ve en sueños como le crucifican, llegando sus clavos a las carnes de Cristo, que estaba detrás.

56. GONZÁLEZ GÓMEZ, Juan Miguel: "La Inmaculada Concepción en la Semana Santa de Sevilla: historia, arte e iconografía", en Actas del Congreso de..... León, 198, pp. 58-63.

57. CONCEPCIÓN, Juan Bautista de la: Un maestro de liberación interior. Comentado por Juan Luis Losada. Madrid, 1977.

58. PUJANA, Juan: San Juan Bautista de la Concepción. Reformador de la Orden trinitaria. Roma, 1975, pp. 33-62.

59. GONZÁLEZ GÓMEZ, Juan Miguel y José María MORILLAS ALCÁZAR: "La orfebrería del Beaterio de la Trinidad de Sevilla: morfología y simbolismo". Op. cit. 
Por ello, su vida y su espiritualidad estarán a partir de entonces marcados con la Cruz ${ }^{60}$.

La pequeña ermita, que porta en su mano izquierda, representa la de Valdepeñas (Ciudad Real). En ella funda el marqués de Santa Cruz, por influencia de Fr. Juan Dueñas, un convento de trinitarios recoletos. Precisamente dicho convento será elegido por San Juan Bautista de la Concepción como cuna de la Descal$\mathrm{cez}^{61}$.

\section{C.2.6. CRISTO ATADO A LA COLUMNA}

Escultura de pasta policromada.

Mide $0,58 \mathrm{~m}$. de alto.

Obra seriada.

Primer cuarto del siglo XX.

A la derecha del arco, que da acceso desde el coro bajo o coro de niñas al templo, hay una consola de caoba con una urna neogótica dorada $(1,45 \times 0,51$ $\mathrm{m}$.), en cuyo interior se expone un Cristo atado a la columna de serie. Con anterioridad ocupó aquel lugar el altarcito de la Virgen del Carmen, que hoy se encuentra en el antecoro ${ }^{62}$.

El Cristo, apolíneo, está atado a una columna cuya altura no alcanza a su cintura, con objeto de que la figura quedase encorvada para la flagelación. Sus manos cruzadas sobre el pilar y su actitud suplicante reflejan la voluntaria aceptación del martirio. La imagen fue donada por D. Francisco Nogales en 1953. En el fuste de la columna, en la zona trasera, conserva el sello que dice: "EL ARTE CRISTIANO. OLOT".

\section{C.3. Esculturas del antecoro}

En el antecoro, dependencia que comunica el claustro con el coro bajo o coro de niñas, hay dos pequeñas imágenes marianas.

\section{C.3.1. VIRGEN DEL CARMEN}

Imagen de candelero para vestir.

Mide $0,55 \mathrm{~m}$. de alto.

Obra anónima sevillana.

Primera mitad del siglo XIX (lám. 11).

60. PUJANA, Juan: Op. cit., pp. 11 y 24.

61. Ibídem, p. 35.

62. A.B.T.S. Obras realizadas en el edificio del Beaterio de la Stma. Trinidad siendo Superiora Madre Pilar Ormad Morillas. 1971-89. Op. cit., nota 30. 
Tras las obras acometidas en el templo del Beaterio, entre 1971 y 1974, se reordenaron litúrgicamente la iglesia, el coro bajo y el antecoro. Como sabemos, entonces se trasladó el retablito de Ntra. Sra. del Carmen, con la imagen titular, desde el coro bajo al antecoro ${ }^{63}$.

: La Virgen se expone en el interior de un pequeño templete neoclásico, sobre una mesa de altar procedente de los antiguos retablos de la iglesia. Todo el conjunto está jaspeado, imitando mármoles. No obstante, las basas, capiteles, cornisas y remates están dorados.

La Virgen del Carmen luce el hábito carmelitano: túnica y escapulario marrón bordado en oro y manto de tisú de plata tachonado de estrellas doradas. La imagen, de nacaradas carnaciones, tiene ojos de cristal con pestañas y cabellera de pelo natural al gusto barroco. En su diestra exhibe el escapulario, atributo propio de esta advocación mariana. Y en la otra porta al Niño Jesús, de marcado carácter deífico, vestido de blanco. Bendice con la diestra y en la otra mano muestra, también, el escapulario.

La Madre porta, sobre la toca de sobremanto de encaje blanco, una corona dorada con pedrería multicolor. Y el Hijo ostenta, sobre su testa, tres potencias de plata como signo de la redención.

\section{C.3.2. VIRGEN DE LOS DOLORES}

Imagen de candelero para vestir.

Mide $0,40 \mathrm{~m}$. de alto.

Obra anónima sevillana.

Primer cuarto del siglo XIX (lám. 12).

Esta pequeña Dolorosa procede de la antigua enfermería. A partir de 1974 se trasladó al antecoro, donde se expone ahora en el interior de una elegante vitrina, de recortados perfiles, decorada con rocallas tardías y elementos vegetales de progenie rococó. Con tal motivo, dicha vitrina fue dorada de nuevo ${ }^{64}$.

Este tipo iconográfico disiente de la Dolorosa sevillana tradicional. Se trata de una nueva interpretación del tema, introducida en los comedios del siglo XVII por Pedro Roldán e inspirada en los modelos granadinos del taller de su maestro Alonso de Mena. Se representa a la Virgen arrodillada, con las manos entrelazadas. Este modelo, que por entonces no debió tener mucho predicamento, se retomó en la Sevilla del setecientos, tras los viajes del Duque Cornejo e Hita del Castillo a Granada ${ }^{65}$.

\footnotetext{
63. Ibídem.

64. Ibid.

65. GONZÁLEZ GÓMEZ, Juan Miguel: "Imágenes de las Cofradías sevillanas desde el Academicismo al Expresionismo realista", en Las Cofradias de Sevilla en el siglo de las crisis. Op. cit., p. 123.
} 
La Dolorosa que nos ocupa viste de negro sobre negro. Inclina, afligida, su cabeza hacia la derecha. Y enlaza sus manos, describiendo un movimiento giratorio hacia la izquierda. Sus aporcelanadas carnaciones responden al gusto estético del momento. Su rostro, con ojos y lágrimas de cristal, queda enmarcado por una argéntea diadema, decorada con ces y guirnaldas de flores y rayos biselados. En el pecho, como es usual, muestra un corazón atravesado por siete puñales que aluden a los siete dolores de María. Esta obra se exhibió en la exposición titulada Fanales y vitrinas de los conventos sevillanos, realizada en el convento de Santa Inés, en 1979, y organizada por la Caja San Fernando de Sevilla ${ }^{66}$.

\section{C.4. Esculturas de la sacristía}

En la sacristía, ubicada tras la capilla mayor de la iglesia del Beaterio, se conservan dos pequeñas esculturas.

\section{C.4.1. CRUCIFICADO}

Escultura en madera policromada.

Mide $0,45 \mathrm{~m}$. de alto.

Obra anónima sevillana.

Primer tercio del siglo XIX (lám. 13).

Este Crucificado se expone en la sacristía del Beaterio sobre una cómoda de caoba neoclásica. Se trata de un Cristo, vivo y suplicante, que se fija a la cruz con tres clavos. Está captado, pues, en su fase premortal. El madero, interpretado como patíbulo de martirio, se atiene al prefacio de la festividad de la Santa Cruz que dice: "et qui in ligno vincebat, in ligno quoque vinceretur" (y quien en el madero venció, en el madero también será vencido) ${ }^{67}$.

El Crucificado, según una tradición medieval, cubre pudorosamente sus caderas con el paño de pureza ${ }^{68}$. Inclina la cabeza hacia la izquierda y eleva su mirada hacia el Altísimo. Una corona de espinas, labrada en plata, ciñe sus sienes, como símbolo de tribulación, sufrimiento y pecado. En ella, según Santo Tomás de Aquino, las ramas recuerdan los pecados veniales y los arbustos los mortales ${ }^{69}$. Y, además, sobre ella despuntan las tres potencias, también de plata.

66. MORALES, A. J. y J. M. SERRERA: Catálogo de la exposición: Fanales y vitrinas de los conventos sevillanos. Sevilla, 1979, pp. 4, 16 y 30.

67. Missale Romanum. Prefacio de la festividad de la Exaltación de la Cruz, 15 de septiembre. Barcelona, 1946.

68. GONZÁLEZ GÓMEZ, Juan Miguel y José RODA PEÑA: "Imagineros e imágenes de la Semana Santa sevillana" (1563-1763). Op. cit., p. 112.

69. FERGUSON, George: Op. cit., p. 32. 
La cabellera, de amplias guedejas, cae por detrás y sobre el hombro izquierdo, equilibrando la lazada del sudario en la cadera derecha. Sobre las tostadas carnaciones resbalan las gotas de sangre que brotan de las llagas y heridas.

La cruz, de formato decimonónico, es cilíndrica. Mide, con la peana, $1,17 \mathrm{~m}$. de altura. En sus extremos se remata con sendas perinolas. La peana, de recortados perfiles, presenta cuatro moldurones en forma de eses contrapuestas. Entre ellos hay una guirnalda de temas vegetales. En el extremo superior del stipes aparece una cartela de plata, decorada con rocallas y ces, con el I.N.R.I.

\section{C.4.2. FANAL DEL PASTORCITO}

Escultura en madera policromada.

Mide $0,15 \mathrm{~m}$. de alto.

Obra anónima.

Primer tercio del siglo XIX (lám. 14).

Este fanal se expone sobre una consola de caoba isabelina con tapa de mármol blanco. Sobre un risco aparece el Pastorcito sentado bajo un arbusto en flor. Ante El se agrupan cuatro ovejitas blancas, entre rosales y matas de margaritas. El Niño Jesús, descalzo, viste túnica de raso rosa con encajes y cíngulo dorado. Debajo lleva calzones con encajes blancos. Su cabeza, inclinada hacia la derecha, presenta una recortada cabellera. El rostro, mofletudo, tiene ojos de cristal y menuda nariz. Resalta el aspecto entrañable de la figurita, las nacaradas carnaciones de sonrosadas mejillas y labios. Como corresponde al modelo iconográfico que nos ocupa, se concede especial interés al sombrero, decorado con florecillas silvestres. Su ancha ala, caída, se vuelve hacia arriba por delante para mostrar el rostro del pequeño Jesús. El Pastorcito en su mano izquierda porta el báculo o cayado, mientras que con la diestra intenta acariciar a las ovejitas. En definitiva, se trata de un bello ejemplar de la devoción popular del momento. 


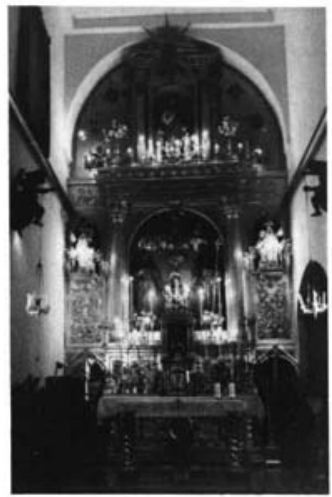

Figura 1

Retablo Mayor.

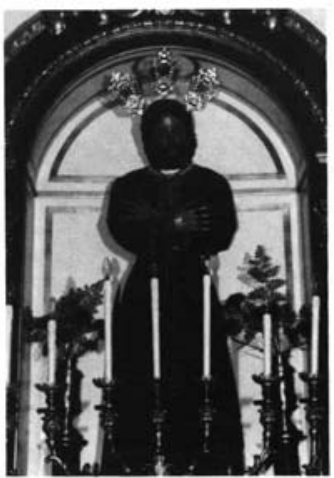

Figura 2

Nuestro Padre Jesús ante Anás. 


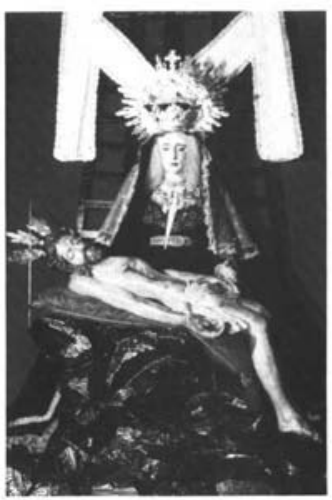

Figura 3

Grupo escultónico de la Piedad.

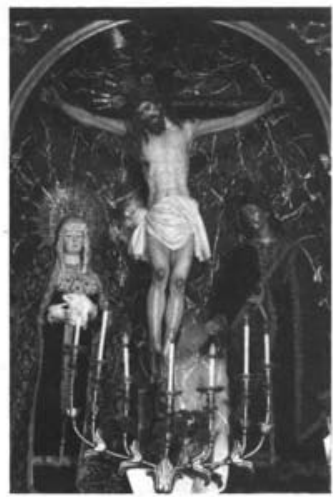

Figura 4

Crucificado, Maria Santisima del Dulce Nombre y San Juan Evangelista. 


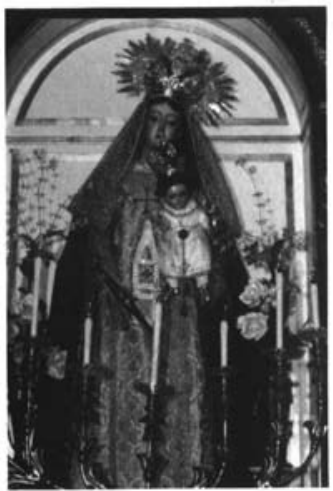

Figura 5

Virgen del Remedio.

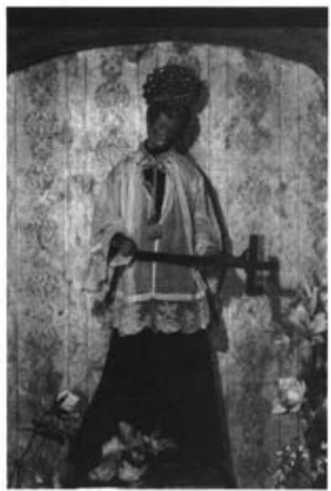

Figura 6

San Luis Gonzaga. 


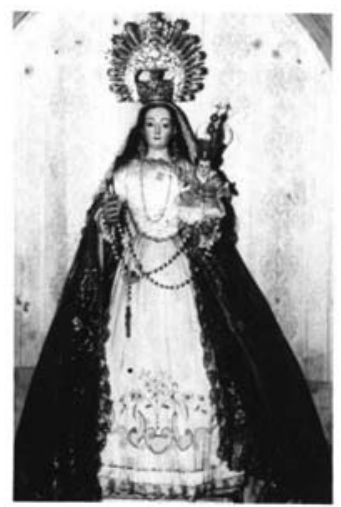

Figura 7

Virgen del Rosario.

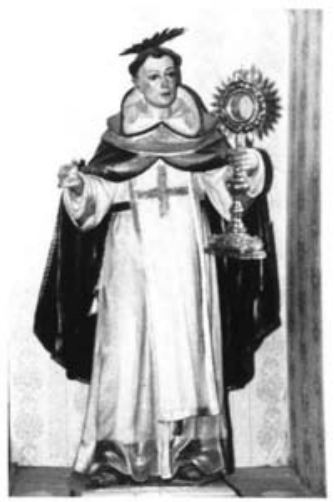

Figura 8

San Miguel de los Santos. 


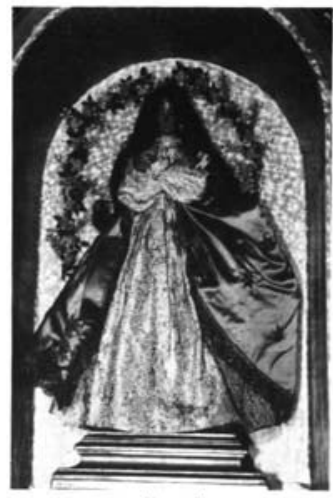

Figura 9

Inmaculada Concepción.

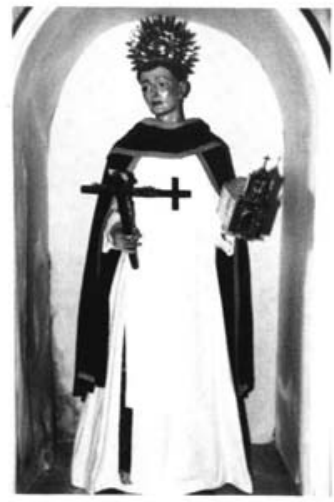

Figura 10

San Juan Bautista de la Concepción. 


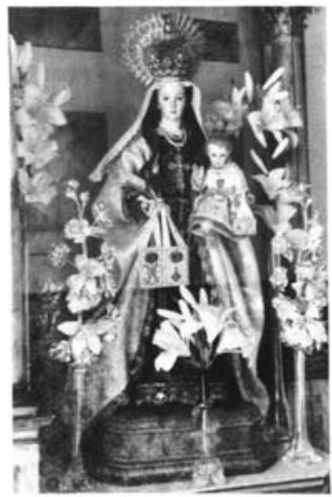

Figura 11

Virgen del Carmen.

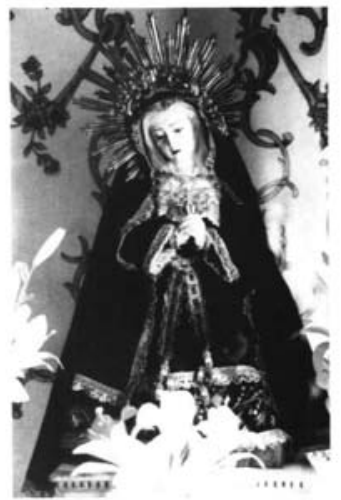

Figura 12

Virgen de los Dolores. 


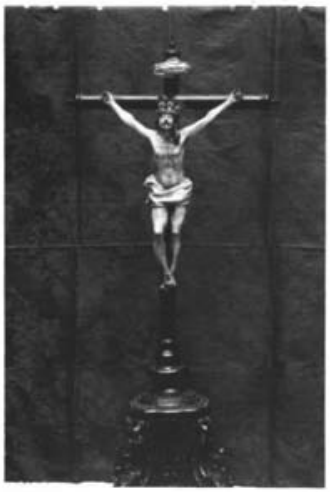

Figura 13

Crucificado.

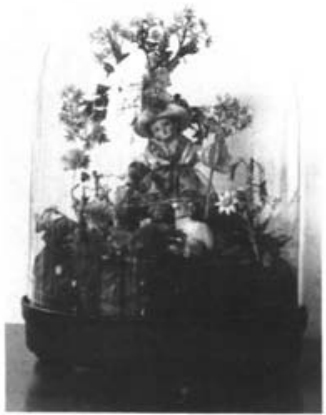

Figura 14

Fanal del Pastorcito. 